\title{
Social Practice within Strategy Communication Process: Power Distance Tension among Top and Middle Managers
}

\author{
Jarrah Al-Mansour \\ AOU Business School, Arab Open University, Kuwait. \\ Demola Obembe \\ Leicester Castle Business School, De Montfort University, United Kingdom.
}

\begin{abstract}
We examine the role of power distance in regulating strategy communication practice among top and middle managers from a social practice perspective. We argue that power distance cannot be treated as a material factor that can be controlled and easily measured beyond organisation boundaries; rather, it is a cultural accumulation of social interactions between organisational members. Based on a single case study with 27 interviews drawn from a Kuwaiti public sector organisation, we found that strengthening communication practices among organisational members and aligning individual- and group-level cognition, are key drivers for successful communication of strategy in public sector organisations. Furthermore, we found that in a high-power distance culture, more powerful individuals are inclined to make autocratic decisions. Equally, organisations with high power distance cultures are prone to deliberate mismanagement and high cultural tension. Our research contributes to the culture literature by exploring the under-researched subject of power distance and the cognitive understanding of social practice.
\end{abstract}

Keywords: Power Distance, Strategy Process, Social Practice, Top and Middle Managers, Strategy Communication

Publication Details: Received 22 Sep 2019; Revised 21 Apr 2020; Accepted 6 June 2020 


\section{Introduction}

In today's dynamic environment, managers at various levels need to ensure reduced cultural tension when communicating organisational strategies, objectives, and dayto-day operational issues. This also requires them to be flexible and to have an open mind-set in order to allow a prompt response to surrounding environmental changes (Huy, 2001). Although flexibility and being open-minded might well be considered key qualities for those in managerial positions, it is unrealistic to expect to encounter cultural tension between various managers on a regular basis, and indeed as part of normal social practice. In real social practice, cultural tension does not occur incidentally; rather, it is the continuous outcome of the social interaction between the organisational social actors. Therefore, providing a unique solution to reducing the cultural tension between managers sounds somewhat unrealistic, especially within a dynamic strategy process. The word 'managers' in this research is used interchangeably with social actors, decision makers, internal actors, and senior organisational members.

In practice, strategy process is highly dependent on clear communication and common, or at similar, understanding among the internal actors (Boyer \& McDermott, 1999; Kellermanns et al., 2005). It also relies on minimal cultural tension between the two and within managerial groups (Yan, 2008; Das \& Kumar, 2010) and consequently on the being minimal conflict among social actors (Currie et al., 2017). As a general definition, culture is viewed as a set of values and beliefs which are considered to be a constitutive component of an interactive social work practice in a multicultural context (Yan, 2008). One of the well-established dimensions that interpret the culture and the cultural complexity of individuals within the workplace is Hofstede's power distance (PD) dimension (Hofstede, 1980, 2001). The PD dimension is a vital lens through which we can develop our understanding of people's interaction within the strategy process. As defined by Hofstede (2001), PD represents the extent to which certain members within a specific context expect and accept the unequal distribution of a certain level of power among various individuals.

Although studies in the field have acknowledged the complexity of the cultural dimension in general and PD in particular (Koc, 2013; Schuder, 2016), many others have treated the concept of culture as a tangible factor that can be easily controlled (Bushardt et al., 2011; Ahmadi et al., 2012). The foundation of these studies and others were built around this argument and were further extended to measure the effect of culture and the PD dimension on other business perspectives. For instance, the effect of culture and PD on the strategy implementation process (Bushardt et al., 2011), on knowledge management (Zheng et al., 2010), on strategy formulation (Struwig and Smith, 2002), on communication styles (Gudykunst et el., 1996), on quality management (Gambi et al., 2015), and on organisational innovation (Laforet, 2016) have all been considered in the literature. 
These research efforts have been guided by various theories and have therefore produced mixed results with regards to the examined cultures. More specifically, most of the research in this area is tied into an examination of the effects of PD on national culture (Earley \& Gibson,1998; Khatri, 2009); on macro- and microcultures (Madlock, 2012); inequalities in societies (Han et al., 2017); international project teams (Paulus et al., 2005); public relations (Sriramesh, 2013); and capital market participants (Krause, 2016). The main focus of this research was on 'external' culture, that is, beyond the limits of the internal culture of firms. However, the effects of this examination do not clearly reflect how the PD dimension actually affects the dominant internal social actors in the first place. Such an effect is vital to both the strategy communication and the strategy implementation processes. Therefore, we attempt herein to bridge this gap in knowledge by understand how PD is internally practiced between decision makers within public sector organisations.

Based on this brief background, whilst the extant literature treats PD as a material factor that can be controlled and easily measured beyond the organisation itself, there is a paucity of understanding as to how PD is actually practiced and agreed upon between two managerial teams in the first place. Our primary goal in this paper is to empirically examine the materiality of PD and how it is practiced between top and middle management teams from a social practice perspective. Such practice is of the utmost priority to understand how it can help to foster the communication and the implementation of various organisational strategies. Therefore, in order to facilitate this purpose, we pose two important questions: 'How is power distance socially practiced between top and middle managers?' and 'How does power distance internally enable the strategy communication and the strategy implementation processes?'.

\section{Background and Theory}

\section{Understanding Power Distance}

Power distance is one of the core dimensions of national culture introduced by Hofstede (1980a, 1980b) and, as such, comparative strategy scholars frequently use it to predict cultural differences and consequent effects on organisational strategy (i.e., Fang \& Jue-Fan, 2006; De Mooij \& Hofstede, 2010). As a general concept, PD refers to the variation in status between social actors within their organisation (Hofstede, 1980a). However, as a conceptual model, as proposed by Hofstede (1980b), PD can be described as 'the extent to which a certain society accepts the fact that power in organisations are unequally distributed'. From another perspective, PD is viewed as the acceptance that less powerful social actors expect unequally distributed power in certain social contexts (Franke et al., 1991). Organisations with high PD cultures, and social actors with no or less power show noticeable deference to those with more power (Yang et al., 2007). 
Societies with relatively low PD in the West, for instance, Great Britain, the USA, Australia, and Denmark, have contributed to the increase in the body of literature on social process, which is based on pure cultural norms and values that do not accept power inequality (Yuan \& Zhou, 2015). However, this might not be the case in high PD cultures including, for instance, Mexico, Hong Kong, Malaysia, and India, which may accept power inequality as an integral part of their social values (Hofstede, 2001). In real practice within organisations, a clear social gap can be seen between social actors at different managerial levels (Javidan et al., 2006). Such practice means that supervisors within a high PD culture deal formally and autocratically with their subordinates. Social actors within high power cultures offer minimal cooperation to subordinates, and accept status differences; and consequently, subordinates end up obeying their commands (Chen \& Aryee, 2007; Kopelman, 2009). Similarly, Kirkman et al., (2009) suggests that subordinates within high PD cultures might perceive their direct supervisors as elite and superior individuals, and consequently will always try to meet their continuous expectations without question. However, direct supervisors should be aware of their subordinates' cultural values and to consequently engage in social practices that match their subordinates' values (Kirkman et al., 2009). Furthermore, the hesitancy of high traditionality individuals to handle work-related tasks may arise from their sense of being less empowered than others (Chen \& Aryee, 2007). Therefore, PD directly influences the way in which social actors interact with each other (Hofstede, 2001).

One argument explaining the vitality of PD strategy research is that power stresses the importance of individuals' social status and job characteristics (Hofstede \& Hofstede, 2005). Furthermore, the extent of PD might negatively influence knowledge sharing and therefore the communication of organisational strategy among social actors at various levels of employment (Ardichvili et al., 2006). Equally, the PD dimension may contribute to unsuccessful implementation of organisational strategies due to inequality in communication practice among organisational members (Greiner et al., 2007). The majority of recent research into PD has focussed on the concept of an international level beyond the organisation, with a clear dearth of knowledge of the dynamics of PD within the organisation itself (i.e., Beugelsdijk et al., 2017).

Although research into international levels enriches both theory and practice, it is of utmost priority to shed further light on the internal dynamics of social actors. We therefore suggest that such a focus actually represents an obstacle to a comprehensive analysis of how PD is practiced between two local heterogeneous groups of internal stakeholders (for instance, top and middle managers). Since the strategy process is based on teamwork and inclusive efforts that involve the cooperation of various social actors from different hierarchal levels, it becomes vital to empirically investigate how PD is socially practiced between top and middle managers with different positional powers and, consequently, how it affects the strategy communication process.

\section{The Role of Social Practice in the Strategy Process}

The lens of social practice offers an alternative perspective to traditional theories in terms of explaining how humans interact given a specific set of contexts (Giddens, 1984; Bourdieu, 1990). As argued by Feldman and Orlikowski (2011), the main focus of the social practice lens is on the dynamic activities of social actors with respect to their strategy practices within their organisations. Social practice theories rely on 
three core principles, namely social interaction, mutual constitution of relations, and duality of relations (Giddens, 1984; Bourdieu, 1990).

Social interaction was viewed by Giddens (1984) as a dynamic construct, which links the production and reproduction of social norms that affect social actors' actions. Similarly, the social interaction was viewed by Bourdieu (1990) as an implicit element, which is responsible for reactivating the sense objectified in institutions (habitus) among social actors. As for the second principle, the principle of mutual constitution was viewed by Giddens to emphasise the relationship between agency and a certain set of structures, and similarly Bourdieu acknowledged that assumptions regarding social actors' practice, habitus, and field all interact with one another to create a set of shared practices and norms. For the third principle, according to Giddens the duality of relations emphasises the agency and structure, while Bourdieu noted the inseparability of the subjective and objective dimensions within a given set of structure.

In a similar manner to many other applications of Social Practice Theory, PD and strategy studies have received considerable attention (Johnson et al., 2003; Greiner et al., 2007; Jarzabkowski, 2008; Gollnhofer \& Turkina, 2015; Wang \& Larimo, 2017). In a closer look at strategy-related research, scholars such as Whittington (2006), and equally Jarzabkowski and Spee (2009), have offered a descriptive perspective that focuses on the analysis of the practitioners, their practices and interactions with each other, and the praxis of the context in which they act. The engagement of different groups of social actors in the strategy process creates an opportunity for 'shared strategic understanding and commitment' (Wooldridge and Floyd, 1990). Thus, to understand the PD and strategy communication relationship, we need to understand the theory of social practice from a cognitive perspective, that is, the complicated relationships of social actors.

\section{Top and Middle Managers' Roles in the Strategy Process}

There is a general belief that strategy practices are a pure and core task for the top management team, who are believed to be an organisation's strategy practitioners, as proposed by some scholars (i.e., Jarzabkowski, 2005; Johnson et al., 2007). Yet, in other sets of research, and indeed sometimes the same researchers, the importance of exploring the strategy practices beyond top management team has been called for to include functional managers' practices (Johnson et al., 2003; Jarzabkowski et al., 2007). This obviously includes the participation of other employees from other hierarchal levels, more specifically the engagement of middle managers, in the strategy communication process. For instance, Wooldridge and Floyd (1990) encouraged the engagement of different managerial levels in the strategy communication process, as such practice creates a shared strategy understanding. Moreover, Powell et al., (2011) have stressed that inter-unit communication is critical for a better organisational fit. 
Similarly, Wooldridge et al., (2008) have shed the light on the importance of aligning both top management and middle management teams in various strategy processes, including formulation and the implementation. Equally, a positive relationship between the involvement of middle management teams in the strategy process and improved strategic change within their organisation was recognised by Ukil and Akkas (2017). They further found that if middle managers are engaged in the strategy communication process, top managers will be in a better position to bridge the informational gap with front-line staff. It is also noteworthy to refer to Powell et al., (2011), who viewed the strategy as a decision context that involves situated managers, and which is surrounded by uncertainty and poorly defined problems, with unknown social and economic consequences. Such surroundings indeed require continuous cooperation rather than tension between top and middle managers to process their organisational strategic initiatives. The continuous tension among social actors may lead to task conflict and consequently a relationship conflict and stress at workplace (Shahzad et al., 2019).

It is further argued that the non-engagement of middle managers in the strategy communication process is mainly due to the belief held by top managers that middle managers do not require such involvement in the decision-making process (Miller et al., 2008). Such a perception will create culture tension and consequently conflict in management among groups of social actors. This view further creates three critical problems with respect to PD - strategy communication-related research. Firstly, research which focuses on the interaction of top management teams has gone far beyond, and has deeply analysed, the intra-top management process in isolation from other employment groups (Carpenter et al., 2004). Secondly, research efforts have been directed toward strategy formulation to a greater extent than the strategy implementation and strategy communication processes (Jarzabkowski, 2008; Sull et al., 2015). Thirdly, very little attention has been given to the interaction between top and middle management teams, which may affect the communication and execution of strategies (Raes et al., 2011).

Research further provides considerable evidence of the importance to creating strategy alignment among both top and middle management teams. However, both parties may have different perceptions of each other, which normally lead to continuous culture tension. For instance, Rigby et al. (2002) claim that middle managers often do not understand what they are implementing, which suggests that a lack of proper communication and disruption to the flow of information occurs at some point, and therefore support is seen a priority from top management who are also responsible for executing strategy-related objectives. Equally, Adamides (2015) argued that the engagement of functional stakeholders in strategy communication processes leads to a greater alignment in the overall organisational strategy. This further strengthens the argument as to why it is important to empirically analyse how PD affects the alignment of strategy communication between the top and middle management levels. 


\section{Methodology}

\section{Sample and Data Collection}

Given the exploratory nature of the study, a qualitative approach was adopted. Data was collected from a single case, public organisation in Kuwait. As the paper enquires on 'how' individuals understand their content-relevant practices within a single context, a single case study is deemed an appropriate choice for unearthing detailed findings (Yin, 2014). Case study usage has become one of the most popular methods of conducting qualitative inquiry as it provides researchers with nuanced, empirically rich, holistic accounts of specific phenomena (Willis, 2014).

Using purposive and snowball sampling techniques, we conducted a total of 27 interviews (Roulston, 2010). Our sample consisted of 10 top managers and 17 middle managers believed to have the relevant skills, knowledge, expertise and experience to most fully enrich the research findings (Noy, 2008). Prior to the fieldwork, the interview protocol was designed to ensure effective coverage of the social phenomenon under investigation, including, for instance, communication processes, managerial conflicts, personal interactions, objectives agreement, decision-making loop, and strategy implementation processes.

The interviews were conducted and finalised over six months. The organisation chosen for this study is one of the most active public sector ministries in the country, whose purview is to provide a wide range of public services to society. The rationale behind this choice is twofold, which position the selected ministry as an ideal fit for the research. Firstly, it is multicultural; with targeted participants reflecting different geographical backgrounds. Secondly, the selected ministry interacts with other public organisations and a large number of private organisations, which reflects its dynamic nature. Six pilot interviews were conducted, and consequently four questions were revised to ensure clarity with respect to technical terms used in the interview protocol (Saunders et al., 2016). Upon completion of the pilot phase, an additional 21 interviews were conducted, giving a total of 27 interviews. Table 1 shows the profile of interviewees. All due ethical considerations were observed with interviewees assured of anonymity along with the Organisation.

Table 1: Interviewee Profile

\begin{tabular}{|c|c|c|c|c|c|c|}
\hline $\mathbf{S} / \mathbf{N}$ & ID & Managerial Level & Gender & $\begin{array}{c}\text { Managerial } \\
\text { Role }\end{array}$ & Job Function & Experience \\
\hline 1 & I-1-MM & $\begin{array}{c}\text { Middle } \\
\text { Management }\end{array}$ & Male & $\begin{array}{c}\text { Departmental } \\
\text { Head }\end{array}$ & Project Supervisor & 8 Years \\
\hline 2 & I-2-MM & $\begin{array}{c}\text { Middle } \\
\text { Management }\end{array}$ & Female & $\begin{array}{c}\text { Departmental } \\
\text { Head }\end{array}$ & $\begin{array}{c}\text { Supervisor in Supply } \\
\text { Projects }\end{array}$ & 8 Years \\
\hline 3 & I-3-MM & $\begin{array}{c}\text { Middle } \\
\text { Management }\end{array}$ & Female & $\begin{array}{c}\text { Departmental } \\
\text { Head } \\
\end{array}$ & $\begin{array}{l}\text { Technical Support } \\
\text { Team Leader }\end{array}$ & 8 Years \\
\hline 4 & I-4-TM-R & $\begin{array}{c}\text { Top Management } \\
\text { (Retired) }\end{array}$ & Male & Division Head & $\begin{array}{c}\text { Manager in Control } \\
\text { Unit and Surveillance }\end{array}$ & 10 Years \\
\hline 5 & I-5-TM & Top Management & Male & Division Head & $\begin{array}{c}\text { Manager in } \\
\text { Maintenance }\end{array}$ & 10 Years \\
\hline 6 & I-6-MM & $\begin{array}{c}\text { Middle } \\
\text { Management }\end{array}$ & Male & $\begin{array}{c}\text { Departmental } \\
\text { Head }\end{array}$ & $\begin{array}{c}\text { Supervisor in } \\
\text { Administrative Affairs }\end{array}$ & 8 Years \\
\hline
\end{tabular}




\begin{tabular}{|c|c|c|c|c|c|c|}
\hline 7 & I-7-TM & Top Management & Female & Unit Head & $\begin{array}{c}\text { Manager in Training } \\
\text { and Research }\end{array}$ & 6 Years \\
\hline 8 & I-8-MM & $\begin{array}{c}\text { Middle } \\
\text { Management }\end{array}$ & Male & $\begin{array}{c}\text { Departmental } \\
\text { Head }\end{array}$ & $\begin{array}{l}\text { Assistant Supervisor } \\
\text { in Media }\end{array}$ & 8 Years \\
\hline 9 & I-9-MM & $\begin{array}{c}\text { Middle } \\
\text { Management }\end{array}$ & Male & $\begin{array}{c}\text { Departmental } \\
\text { Head }\end{array}$ & $\begin{array}{c}\text { Networks Team } \\
\text { Leader }\end{array}$ & 8 Years \\
\hline 10 & I-10-MM & $\begin{array}{c}\text { Middle } \\
\text { Management }\end{array}$ & Male & $\begin{array}{c}\text { Departmental } \\
\text { Head }\end{array}$ & $\begin{array}{c}\text { Consumer Affairs } \\
\text { Consultant }\end{array}$ & 8 Years \\
\hline 11 & I-11-TM & Top Management & Male & Division Head & $\begin{array}{l}\text { Manager in Projects } \\
\text { and Networks }\end{array}$ & 10 Years \\
\hline 12 & I-12-MM & $\begin{array}{c}\text { Middle } \\
\text { Management }\end{array}$ & Female & $\begin{array}{c}\text { Departmental } \\
\text { Head }\end{array}$ & $\begin{array}{l}\text { Assistant Supervisor } \\
\text { in Maintenance }\end{array}$ & 8 years \\
\hline 13 & I-13-MM & $\begin{array}{c}\text { Middle } \\
\text { Management }\end{array}$ & Male & $\begin{array}{l}\text { Departmental } \\
\text { Head }\end{array}$ & $\begin{array}{l}\text { Quality Assurance } \\
\text { Team Leader }\end{array}$ & 8 years \\
\hline 14 & I-14-MM & $\begin{array}{c}\text { Middle } \\
\text { Management }\end{array}$ & Male & $\begin{array}{c}\text { Departmental } \\
\text { Head }\end{array}$ & $\begin{array}{c}\text { Consultant in } \\
\text { Administrative Affairs }\end{array}$ & 8 years \\
\hline 15 & I-15-MM & $\begin{array}{c}\text { Middle } \\
\text { Management }\end{array}$ & Male & $\begin{array}{c}\text { Departmental } \\
\text { Head }\end{array}$ & $\begin{array}{l}\text { Assistant Team leader } \\
\text { in Legal Affairs }\end{array}$ & 8 years \\
\hline 16 & I-16-MM & $\begin{array}{c}\text { Middle } \\
\text { Management }\end{array}$ & Male & $\begin{array}{c}\text { Departmental } \\
\text { Head }\end{array}$ & $\begin{array}{c}\text { Supervisor in } \\
\text { Operation and } \\
\text { Maintenance }\end{array}$ & 8 years \\
\hline 17 & I-17-MM & $\begin{array}{c}\text { Middle } \\
\text { Management }\end{array}$ & Male & $\begin{array}{c}\text { Departmental } \\
\text { Head }\end{array}$ & $\begin{array}{c}\text { Supervisor in } \\
\text { Technical Services }\end{array}$ & 8 years \\
\hline 18 & I-18-TM & Top Management & Male & Division Head & $\begin{array}{l}\text { Manager in Networks } \\
\text { Maintenance }\end{array}$ & 10 years \\
\hline 19 & I-19-MM & $\begin{array}{c}\text { Middle } \\
\text { Management }\end{array}$ & Male & $\begin{array}{c}\text { Departmental } \\
\text { Head }\end{array}$ & $\begin{array}{c}\text { Supervisor in } \\
\text { Technical Control }\end{array}$ & 8 years \\
\hline 20 & I-20-MM & $\begin{array}{c}\text { Middle } \\
\text { Management }\end{array}$ & Male & $\begin{array}{l}\text { Departmental } \\
\text { Head }\end{array}$ & Production Supervisor & 8 years \\
\hline 21 & I-21-TM & Top Management & Male & Division Head & $\begin{array}{l}\text { Manager in Bids and } \\
\text { Internal Affairs }\end{array}$ & 10 years \\
\hline 22 & I-22-MM & $\begin{array}{c}\text { Middle } \\
\text { Management }\end{array}$ & Male & $\begin{array}{c}\text { Departmental } \\
\text { Head }\end{array}$ & $\begin{array}{c}\text { Employment Team } \\
\text { Leader }\end{array}$ & 8 years \\
\hline 23 & I-23-TM & Top Management & Male & Division Head & $\begin{array}{c}\text { Manager in Project } \\
\text { Design }\end{array}$ & 10 years \\
\hline 24 & I-24-TM & Top Management & Male & Division Head & $\begin{array}{c}\text { Manager in Financial } \\
\text { Affairs }\end{array}$ & 10 years \\
\hline 25 & I-25-TM & Top Management & Male & Division Head & $\begin{array}{l}\text { Manager in Planning } \\
\text { and Follow-Up }\end{array}$ & 10 years \\
\hline 26 & I-26-MM & $\begin{array}{c}\text { Middle } \\
\text { Management }\end{array}$ & Male & $\begin{array}{c}\text { Departmental } \\
\text { Head }\end{array}$ & $\begin{array}{l}\text { Assistant Team Leader } \\
\text { in Internal Quality } \\
\text { Assurance }\end{array}$ & 8 years \\
\hline 27 & $\begin{array}{c}\text { I-27-TM- } \\
\text { R }\end{array}$ & $\begin{array}{l}\text { Top Management } \\
\text { (Retired) }\end{array}$ & Male & Division Head & $\begin{array}{l}\text { Manager in Training } \\
\text { and Development }\end{array}$ & 10 years \\
\hline
\end{tabular}

Additional note: Due to ethical considerations and at the organisation's request, the job functions of the interviewees are anonymised 


\section{Data Analysis and Coding}

The research questions were set to seek managers' own experiences, backgrounds, stories, expectations, and beliefs with regard to the phenomena under investigation. Such study requires active engagement with participants; therefore, we adopt an inductive reasoning approach, which is widely adopted in many qualitative studies (e.g., Bryman and Burgess, 1994; Dey, 2003). Furthermore, the inductive approach relies on how researchers effectively use the details of the phenomena gathered, indepth readings, and understanding of the raw data to develop themes through the interpretation of collected data (Thomas, 2006).

Data collected from the interviews were analysed manually. The analysis and coding process began by assigning open codes to the interview questions. The codes were aggregated to form sub-themes in order to create a sense of meaning. In terms of the open codes, we coded all instances in which both top and middle managers identified their own interactions as normal practices of PD between them. This procedure was followed by classifying the interactions' dispositions into two main categories, namely PD and cultural tension for both top and middle managers. Thus, a number or phrases and key words acknowledged by top managers were coded to include, for instance, statements about agreement, positional power, strategy ownership, unlimited authority, tenure, and experiences. Equally, phrases and key words coded for middle managers included; statements about openness, ethical behaviour, cooperation, conflict avoidance, priorities of objectives, and freedom of opinion. Table 2 below reveals the code commonalties across the entire set of interviewees.

Table 2: Theme and Code Commonalities across the Interviews

\begin{tabular}{|c|c|c|c|c|}
\hline Themes & Relative Codes & Respondents & Similar Words & Interviews \\
\hline $\begin{array}{l}\text { Social } \\
\text { networks }\end{array}$ & $\begin{array}{l}\text { Protection } \\
\text { Culture Aspect }\end{array}$ & 22 & $\begin{array}{l}\text { Lack of consensus, } \\
\text { different views, deny } \\
\text { promises, strategic } \\
\text { joining, strategy } \\
\text { changes, culture aspect, } \\
\text { needs enforcement, } \\
\text { open door policy, } \\
\text { protection }\end{array}$ & $\begin{array}{l}2-5,7-11,13 \\
15,17-27\end{array}$ \\
\hline $\begin{array}{l}\text { Cultural } \\
\text { tension }\end{array}$ & $\begin{array}{l}\text { One-man show } \\
\text { Tribes } \\
\text { Code of } \\
\text { Conduct }\end{array}$ & 20 & $\begin{array}{l}\text { Personal decisions, one- } \\
\text { man show, line of } \\
\text { command, different } \\
\text { mind-sets, positional } \\
\text { power, social } \\
\text { connections, tribes, } \\
\text { professional practice, } \\
\text { code of conduct }\end{array}$ & 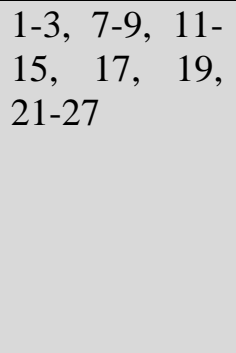 \\
\hline $\begin{array}{l}\text { Individual } \\
\text { Authority }\end{array}$ & $\begin{array}{l}\text { Legitimate } \\
\text { Practice } \\
\text { Ownership }\end{array}$ & 16 & $\begin{array}{l}\text { Strategy ownership, } \\
\text { unlimited authority, } \\
\text { legitimate practice, } \\
\text { cultural phenomenon, } \\
\text { mean of power, } \\
\text { teamwork spirit, public } \\
\text { service ethos }\end{array}$ & $\begin{array}{l}3-4,6,9-11 \\
16-18,20-22 \\
24-27\end{array}$ \\
\hline
\end{tabular}


Data analysis was guided by the six-stage thematic analysis approach, widely known to make qualitative research results available to a wider audience (Braun et al., 2019). It also aids researchers in comparing theory and practice simultaneously (Hudson et al., 2001). The total number of interview transcripts analysed was 27 , accounting for 167 pages, generating more than 55 potential sub-themes. Within the process of data reduction, commonalities were linked and irrelevant codes were consequently excluded. The data reduction process resulted in three main themes use in narrative development. Figures 1 and 2, respectively, represent a sample map of the associated data coding and the final three main themes associated with their respective subthemes.

Figure 1: Sample Map of the Data Coding

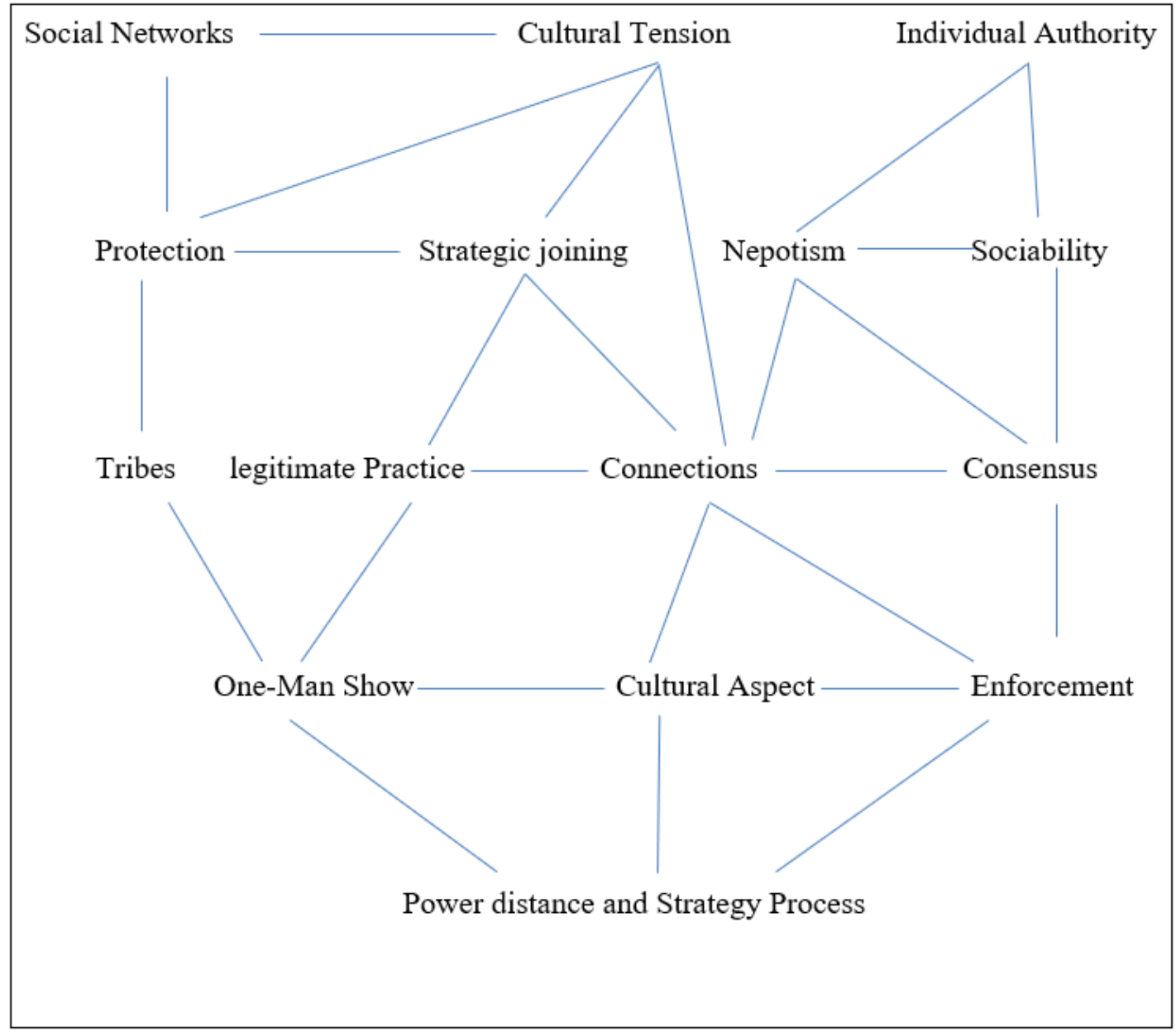


Figure 2: Final Thematic Map of Themes and Sub-Themes (Data Structure)

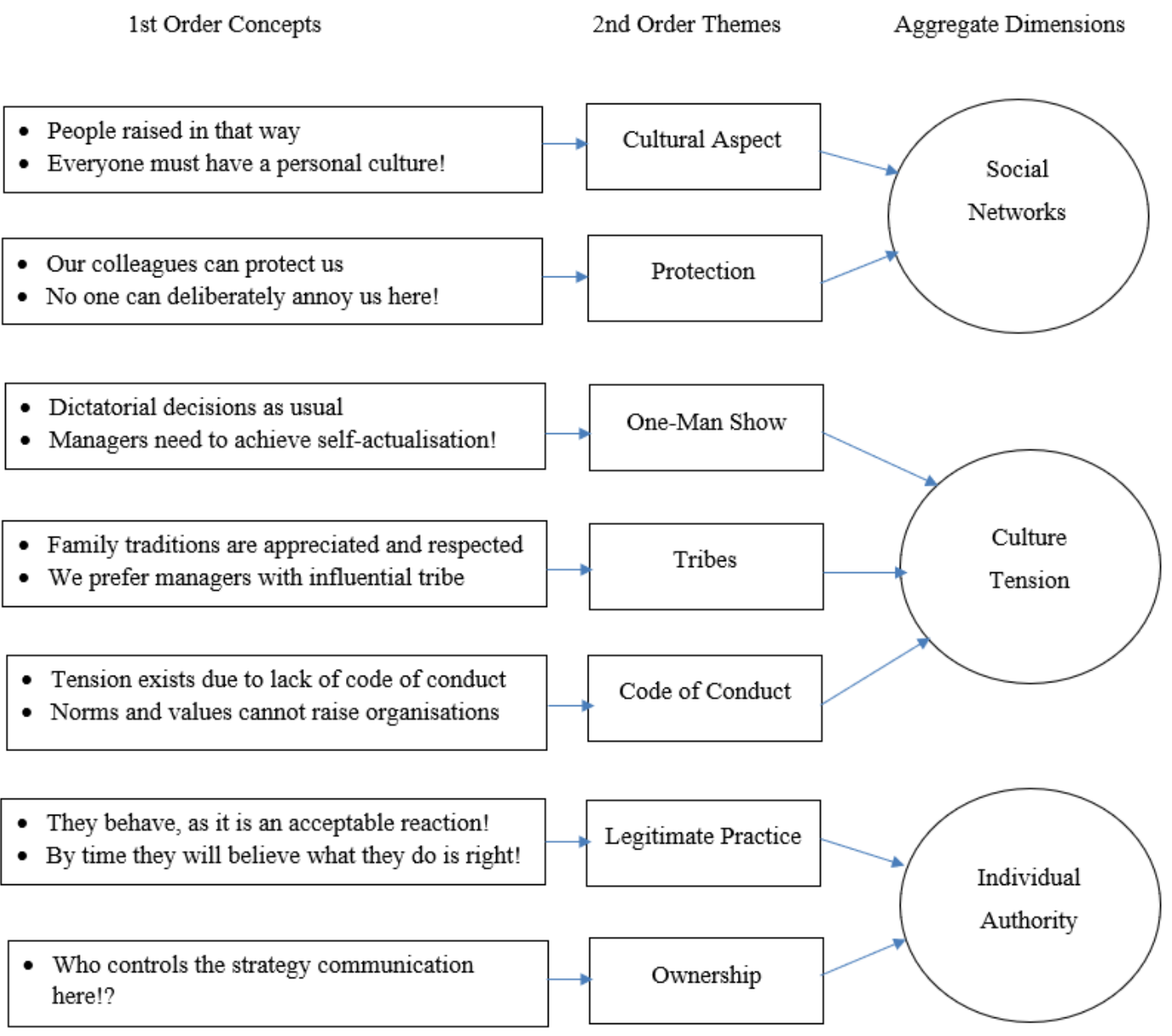

Source: Adapted from Corley and Gioia (2004)

\section{Empirical Data and Findings}

The findings show that the extent of the social networks amongst top and middle managers does influence the way in which strategies are communicated as well as implemented. Social networks were found to be vital as they regulate the social interaction of top and middle managers in developing shared understanding through which to communicate the organisational strategy. Interestingly, due to the social network complexity, it was hard to create shared understanding and equally strategic consensus among internal social actors. This was also why some managers manage their subordinates autocratically. Most participants showed that their positional power is something of value that allows them to be powerful and influential within their context. 
This finding was common across representative quotes from 22 of the 27 interviewees. Below are sample quotes that show the direct effect of the social networks on top and middle management teams in regulating strategy, and consequently in creating a gap in compunction between them. These quotes represent free-narrative responses of selected interviewees.

"I receive orders from top management and transfer it to my subordinates...my staff should not be engaged in discussing these orders with me...I think they are useful only at implementing such orders!'. (I-3-MM)

Middle manager 3 clearly indicates that strategy communication is taking a vertical approach in a top-to-bottom manner. The words 'receiving' and 'transferring' imply that employees at various levels do not exchange strategy-related information. The quote also revealed that the above respondent does not support the participation of lower-level subordinates in the decision-making loop and in discussion of the instructions they receive. This view is also shared by top manager 11, who argued:

"Every organisation has thinkers and doers...after long years of experience, I personally think that not everyone should engage in our discussion unless he is at our managerial level!". (I-11-TM)

Top manager 11 clearly segregates top management and other employment levels through his use of the terms 'thinkers' and 'doers'. We can infer that managers at both managerial levels might have different mind-sets and counter-opinions. Both however seem to rely on their social networks to protect themselves in the workplace. This view was shared among 19 interviewees as exemplified by the following quotes:

"We should communicate in the way we see appropriate!...all our colleagues whom we rely on support us!". (I-25-TM)

"Sharing strategy and communication in general is up to us...we have the upper hand here as we know so many influential people!”. (I-27-TM-R)

The above respondents would suggest that top management represents the most important social actors within the organisation. Their positional role seems to grant them the authority to practice strategy communication the way they see appropriate, even if this is not the most suitable way for the other social actors involved. It can also be inferred from the above that the more influencers you know, the more protection you may have, should critical problems occur. The reliance on social networks is also seen to be an integral part of the cultural context, as shared by 17 interviewees and exemplified below:

"Only top management team should be blamed! The reason is simply because they rely on their connections to do what they want ... and so we do the same!". (I-9-MM)

"Most of our problems are solved through our connections and not through the formal code of practice...this is the reality!". (I-10-MM) 
The above quotes revealed that the level of one's connections obviously play a vital role in regulating individuals' practices. The interviewees further extended to inform that connections provide social protection for individuals. Middle manager 9 also states that the practice they follow is in fact inherited from the practice followed by the top managers. Equally, middle manager 10 argued that organisational issues are in most cases resolved by social interaction through the mediating role of individuals' social networks. The interviewees seem to take a somewhat positive tone towards replacement of the formal code of practice by the more traditional social networks, norms, and social values. It seems that such an approach is preferred by senior managers in organisations.

Although social network levels may strengthen the positions of top and middle managers by allowing for the temporary protection of their relative social practices, the same levels of network might create strong cultural tensions, as stated by 20 interviewees. This is exemplified below:

"What I need in my department I take it immediately whether top management agree or not...If they think they are powerful, we think we are powerful too!". (I-9-MM)

The above comment seems to offer a personal challenge to the top management. The comment implies that the daily work is smoothly processed even without the approval of top managers. It can also be inferred that top management might resist the ideas expressed by middle managers; however, such resistance is of little or no value if middle managers and other employees share their positional power equally. Such practice could be seen as part of proving self-confidence and deserving of a chance to lead, as suggested by a respondent:

"Middle managers sometimes act inappropriately, especially with us...in many cases their argument has no strong evidence... maybe they need to show us their capability to be future leaders or so!". (I-24-TM)

On the other hand, managers who apparently belonged to strong 'tribes' could be more inflexible in terms of sharing responsibility for decisions with others. Furthermore, social actors who belong to similar tribes may be more willing to share ideas and communicate openly with each other. This view was shared by 16 interviewees and is reflected in the following sample quote:

"I trust someone who is my relative or someone who shares a similar family name more than others, unless I've known them for years and are connected by a relation outside the ministry boundaries!'”. (I-21-TM)

The excerpt confirms that social connection and family ties play an important role in facilitating strategy communication and mitigating cultural tension among managers. Here, sharing information is mainly related to how close the person is to the manager. This is also noted in the flowing quote by a middle manager, who argued:

"We prefer to rely on people who we share blood with...those won't harm us as we're connected by social values which are stronger than work rules and procedures!”. (I-22-MM) 
Although this middle manager noted his preference to openly interact with relatives, others disagreed with this view, preferring to work to codes of conduct to maintain the spirit of a professional organisation. This notion was repeated among 15 managers and exemplified below:

"I was educated abroad, and I like to follow approved rules and instructions...otherwise the situation is just a mess!'. (I-1-MM)

"My role is to enforce the use of rules and procedures...I can't allow other communication practices to be followed apart from the rules and procedures". (I-27-TM-R)

The above managers both opine that codes of conduct should be enforced, as opposed to use of social networks. However, it is noteworthy that each manager considered such enforcement from their own perspectives. It seems that for middle manager 1, foreign education was critical to being an independent person, rather than being one who might be affected by strong social norms. By contrast, the top manager viewed enforcing rules as vital as he believes that his positional power grants him the authority to do so.

Poor communication and strong culture between middle and top managers could also be due to the personal authority of managers themselves, which results in awkward situations on a regular basis. This theme was mentioned by 16 top and middle managers. The following are representative quotes from interviewees, which indicate the influence of personal authority within the organisation.

"Sometimes you need to be aggressive...you can't just be kind all the time...we have work to do... and this sometimes requires us to act personally!". (I-3$\mathrm{MM})$

"We're under stress, we can't refer back to formal channels, we need to enforce our opinions and practice our power, this our job as senior managers, and our practice should be acceptable!". (I-11-TM)

"Here we just receive orders...I was involved in many situations when myself and my staff act according to what we think will please the top management team!”. (I-17-MM)

Middle manager 3 opines that imposing personal power (show of force) as part of social practice is sometimes preferable when communicating required objectives. This view is similarly shared by top manager, which may be indicative of cultural tensions between the two levels. Furthermore, from top management perspective, it seems the more positional seniority a manager has, the more space there is to act personally and deviate from nominal formal codes of conduct. It can also be inferred from the above quote that top managers' designated work pressures may be a major factor as to why they act personally and therefore increase cultural tension between themselves and their subordinates. Adopting irregular communication practices also provides grounds for these managers to legitimise their approach. Although managers practice strategy communication personally, their practice could merely be an excuse for lack of willingness to communicate strategy content due to their sense of strategy ownership. Apparently, top managers tend to take ownership of strategy and be 
reluctant to share strategy content, at least in the entirety. Middle managers also are left unaware, or at best partially aware, of the strategies. Such practice should alert decision makers to the need to promote the spirit of teamwork and public service ethos among organisational members and to reduce cultural tension between managers as well as to encourage good communication practices.

\section{Discussion}

Based on our research findings, we argue that whilst respondent views varied according to their subjective perspectives, aligning both management teams, in terms of the strategy communication process followed within public sector organisations, is a step in the right direction. We further found that the positional role of both management levels during the strategy communication process is extremely complex within the strategy process context. What is of interest is not the complexity itself, but the strategy practice of more powerful social actors in communicating strategy-related objectives to less powerful organisational members. The positional role of most powerful managers in communicating required strategic objectives is in line with Jarzabkowski et al. (2007), who suggested that stakeholders at various employment levels could make divergent choices as a result of the different situations that may arise. This suggests that strategy alignment between the two managerial groups is important to both reducing cultural tension and in realising organisational strategies.

Our research findings also suggest that strengthening communication practice between organisational members and aligning both individual- and group-level cognition are key drivers for successful strategy communication in public sector organisations. Powell et al. (2011) similarly opined that such alignment and cognition allows for direct comparison among different groups, and for determining overall fit in an organisation. Such agreement is considered essential to achieving strategic objectives and to reducing cultural tension to a minimum. Furthermore, as Kellermanns et al. (2005) note, a cooperative social environment between social actors is vital to the strategy communication process.

The findings of this research also demonstrate that organisations with high PD cultures are prone to deliberate mismanagement and high cultural tension. This is in line with Chen and Aryee (2007) who argued that social actors with high PD may accept status differences and consequently subordinates obey their supervisors' commands. Such practice may go beyond conflict management and cultural tension to include abusive supervisory behaviour between top and middle management teams. This is echoed by a number of recent research suggestions, which offers potential explanation as to why such practices exist. For instance, Javidan et al. (2006), and Kirkman et al. (2009), argue that subordinates with high PD cultures may consider their direct managers to be elite and superior, and therefore attempt to meet all their expectations.

Our research also indicates the fact that in a high PD culture, the majority of powerful individuals make decisions in autocratically. This seemed obvious in public sector organisations as social actors are protected by their social networks, as opposed to operating under an agreed code of conduct. The complicated nature of social networks amongst top and middle managers was found to influence their ability to achieve 
shared understanding with respect to communication practice. As argued by Jarzabkowski (2005), within the practice lens, strategy is viewed as a situated and socially accomplished activity among social actors. Due to these networks and levels of connection, some managers might well be disinterested in being involved with strategy communication processes and information sharing; rather, they venerate their line managers' connections above everything else in order to secure a healthy relationship within their personal working environments. The questionable use of social networks over functional networks can affect the alignment of strategy communication and consequently hinder the effective execution of strategy, as well as increase cultural tension between top and middle managers.

Social networking was an anticipated theme that emerged from this study, which was due to the background and ethnicity of social members. Securing social networks and connections is a complicated task within public sector organisations, as relations have been found to be more effective in securing individual positions than the normal system. Furthermore, social networks empower social actors with the legitimate authority to behave in the way they see fit within organisations. Managers with strong relational ties and social networks are even viewed as being good leaders by their subordinates, and therefore are strongly influential in terms of what they communicate to others. Anderson (2008) shared the same view as he found that the characteristics of social networks can affect information exchange among stakeholders, and this effect is stronger amongst managers who are willing to benefit from such networks. The main risk of social networks is that they may result in the top and middle management teams allowing the organisational strategy to 'drift' as opposed to what was originally planned, which in turn results in a lack of strategic communication and the potential chance of cultural tension between them.

The fact that social actors rely heavily on their social networks while interacting with each other requires decision makers to align similar mind-sets to reduce any possible cultural tension and to ensure a smooth strategy communication process. In Social Practice Theory, Bourdieu (1990) argued that in the interaction between two agents or groups of agents endowed with the same habitus (Say A and B), everything takes place as if the actions of each of them (Say a1 for A) were organised by reference to the reactions which they call forth from any agent possessing the same habitus (say b1 for B)' (p. 61). This explanation emphasises the idea that personal characteristics play a significant role in regulating the strategic practices of both top and middle managers.

\section{Conclusion}

The aim of the research was to examine the effect of PD on the positional role of top and middle managers during the strategy communication process from the perspective of a social practice lens. Based on the above, our research can be said to have extended the knowledge of PD research in three ways. Firstly, this research has demonstrated the importance of PD as well as cultural tension toward the strategy communication process, as taking into consideration two managerial groups. More specifically, our research has shown that aligning similar individuals' mind-sets is key to fostering effective communication practice. Secondly, we have provided qualitative evidence for the PD and cultural tension - social practice relationship. That is, we 
were able to demonstrate that PD cannot be treated as an object which can be easily measured; rather, it is a social interaction which requires a deeper understanding of individuals' behaviour within the various employment levels. Thirdly, our research introduces a vital contribution to the under-researched area of PD as well as cultural tension between two managerial levels (top and middle management teams). Moreover, it is worth noting that, to our best of knowledge, our study has been the first to simultaneously examine the effects of PD and cultural tension between two managerial levels based on qualitative data. Our research also offers new insight into how PD is actually practiced and agreed between two managerial teams using the social practice lens.

\section{Directions for Future Research}

Future research in this field should consider focusing on the PD dimension and consequent cultural tension in different ways. For instance, the focus of this research was on the PD dimension within the strategy communication process only, and therefore future research should consider other strategy stages, including formulation and implementation. Furthermore, the focus of this work concentrated mainly on the interaction between top and middle management teams, and can therefore be extended to shed light on the interactions within the group itself. Future research might also include other employment levels such as front-line managers and front-line employees. Moreover, a challenging extension to this research would be to focus on both the positional role of managers as well as their nationalities in order to determine how PD aligns both career and personal characteristics simultaneously. Additionally, future researchers are encouraged to integrate the PD literature from the strategy-aspractice lens for more inclusive insights into this area. Also, this study can be applied in other public sector organisations, as well as in the private sector, to allow for direct comparisons.

\section{Implications for Asian Business Context}

To gain better work performance, managers at various organisational levels need to ensure reduced cultural tension between them when communicating their organisational strategies, objectives, and day-to-day operational issues to their subordinates. This further requires regulating strategy communication practices between managers and their subordinates, especially in the Asian context which is considered a collective society by its nature. In such societies, social practices that rely in the first instance on social values, traditions, and norms are generally perceived as being more critical than normal work norms and procedures which can be derived from the interpretation of the PD dimension. Therefore, the aim of this study is to empirically examine the materiality of PD and how it is practiced between top and middle management from a social practice perspective. The research findings suggest that strengthening the communication practice among organisational members and aligning both individual- and group-level cognition are key drivers to the successful communication of strategy in public sector organisations. In order to achieve this, both top- and middle managers need to adopt an open-door policy, encourage two-way communication, and each group of managers need to act as consultant social actors for one another, rather than as competitors. 
The findings of this research also demonstrate that managers with high PD are prone to deliberate mismanagement and high cultural tension with other organisational members. Therefore, policy makers in public sector organisations need to plan and invest in additional social engagement programmes to mitigate possible feelings of repulsion between members. Such programmes could be used to provide counsellors in the workplace, employ more active and positive supervisors, align similar mindsets cross-functional teams, and encourage flexibility. Policy makers also need to pay particular attention to social networking within organisations due to the strong social ties between organisational members. These social networks are seen as secure shields to protect their members. Therefore, policy makers need to initiate relative policies and procedures that encourage formation of social ties and ensure information sharing within the strategy communication process and, consequently reduce the bias and culture tension between organisational members.

Furthermore, the research found that the level of one's connections obviously play a vital role in regulating individuals' practices. Employees in this essence will be loyal to managers who have strong social connection rather than managers with high competences. The level of such connections may strengthen the positions of top and middle managers by allowing for the temporary protection of their relative social practices, the same levels of networks might create strong cultural tension. Such situation might create job tension and stress at workplace, which in turn could affect the productivity of talented employees. Therefore, policy-makers need to invest in human capital and encourage the formation of effective code of practice rather than replying of social connection to be the default standard for social practice. The absence of official code of practice may allow managers at various levels to manage their subordinates autocratically.

Raising with a collective society, the influential powers is valued among members, and therefore, positional power is perceived as a value that allows members to be influential within their context. The autocratic leadership due to power tension was found to influence the ability of reaching a shared understanding between managers and their subordinates with respect to communication practice. Beside the lack of shared understanding and proper communication between autocratic managers and their subordinates, this style of practice could lead to reducing employees' morale over the long-term span. Policy-makers are therefore encouraged to adopt and effective monitoring mechanism of the various levels management that is supported with continuous feedback loop and accountability for implementing corrective actions when necessary.

\section{References}

Adamides, E., (2015), "Linking operations strategy to the corporate strategy process: A practice perspective", Business Process Management Journal, vol. 21, no. 2, pp. 267287.

Ahmadi, A., Ali, S., Salamzadeh, Y., Daraei, M., \& Akbari, J., (2012), "Relationship between organizational culture and strategy implementation: Typologies and dimensions", Global Business and Management Research, vo. 4, no. 3/4, pp. 286-299. 
Anderson, M., (2008), "Social networks and the cognitive motivation to realize network opportunities: A study of managers' information gathering behaviors", Journal of Organizational Behavior, vol. 29, no. 1, pp. 51-78.

Ardichvili, A., Maurer, M., Li, W., Wentling, T., \& Stuedemann, R., (2006), "Cultural influences on knowledge sharing through online communities of practice", Journal of Knowledge Management, vol. 10, no. 1, pp. 94-107.

Beugelsdijk, S., Kostova, T., \& Roth, K., (2017), "An overview of Hofstede-inspired countrylevel culture research in international business since 2006", Journal of International Business Studies, vol. 48, no.1, pp. 30-47.

Bourdieu, P., (1990), The logic of practice, Polity Press, Cambridge.

Boyer, K., \& McDermott, C., (1999), "Strategic consensus in operations strategy", Journal of Operations Management, vol. 17, no. 3, pp. 289-305.

Braun, V., Clarke, V., Hayfield, N., \& Terry, G., (2019), "Thematic analysis", Handbook of Research Methods in Health Social Sciences, pp.843-860.

Bushardt, S., Glascoff, D., \& Doty, D., (2011), "Organizational culture, formal reward structure, and effective strategy implementation: A conceptual model", Journal of Organizational Culture, Communications and Conflict, vol. 15, no. 2, pp. 57-70.

Carpenter, M., Geletkanycz, M., \& Sanders, W., (2004), "Upper echelons research revisited: Antecedents, elements, and consequences of top management team composition", Journal of Management, vol. 30, no. 6, pp. 749-778.

Corley, K., \& Gioia, D., (2004), "Identity ambiguity and change in the wake of a corporate spin-off", Administrative Science Quarterly, vol. 49, no. 2, pp. 173-208.

Currie, D., Gormley, T., Roche, B., \& Teague, P., (2017), "The management of workplace conflict: Contrasting pathways in the HRM literature", International Journal of Management Reviews, vol. 19, no. 4, pp. 492-509.

Das, T., \& Kumar, R., (2010), "Inter-partner sensemaking in strategic alliances: Managing cultural differences and internal tensions", Management Decision, vol. 48, no. 1, pp. $17-36$.

De Mooij, M., \& Hofstede, G., (2010), “The Hofstede model: Applications to global branding and advertising strategy and research", International Journal of advertising, vol. 29, no. 1 , pp. 85-110.

Denscombe, M., (2014), Ground rules for social research: Guidelines for good practice (5th Ed.), Open University Press, Maidenhead.

Dey, I., (2003), Qualitative data analysis: A user friendly guide for social scientists, Routledge, London.

Earley, P., \& Gibson, C., (1998), "Taking stock in our progress on individualismcollectivism: 100 years of solidarity and community", Journal of Management, vol. 24, no. 3, pp. 265 - 304.

Eisenhardt, K., Kahwajy, J., \& Bourgeois, L., (1997), "Conflict and strategic choice: How top management teams disagree", California Management Review, vol. 39, no. 2, pp. 4262.

Fang, S., \& Jue-Fan, W., (2006), "Effects of organizational culture and learning on manufacturing strategy selection: An empirical study", International Journal of Management, vol. 23, no. 3, pp. 503-514.

Flick, U., (2014), An introduction to qualitative research (5th Ed.), Sage, London.

Franke, R., Hofstede, G., \& Bond, M. (1991), "Cultural roots of economic performance: A research note", Strategic Management Journal, vol. 12, no. S1, pp. 165-173.

Gambi, L., Boer, H., Gerolamo, M., Jørgensen, F., \& Carpinetti, L., (2015), "The relationship between organizational culture and quality techniques, and its impact on operational performance", International Journal of Operations and Production Management, vol. 35 , no. 10 , pp. 1460-1484.

Giddens, A., (1984), The constitution of society: Outline of the theory of structuration, Polity Press, Cambridge.

Gollnhofer, J., \& Turkina, E., (2015), "Cultural distance and entry modes: Implications for global expansion strategy”, Cross Cultural Management, vol. 22, no. 1, pp. 21-41. 
Greiner, M., Böhmann, T., \& Krcmar, H., (2007), “A strategy for knowledge management”, Journal of Knowledge Management, vol. 11, no. 6, pp. 3-15.

Gudykunst, W., Matsumoto, Y., Ting-Toomey, S., Nishida, T., Kim, K., \& Heyman, S., (1996), "The influence of cultural individualism-collectivism, self construals, and individual values on communication styles across cultures", Human communication research, vol. 22, no. 4, pp. 510-543.

Han, D., Lalwani, A., \& Duhachek, A., (2017), "Power distance belief, power, and charitable giving", Journal of Consumer Research, vol. 44, no. 1, pp. 182-195.

Hofstede, G., (1980), Culture's consequences, international differences in work-related values, Sage, California.

Hofstede, G., (1980a), Culture's consequences, international differences in work-related values, Sage, California.

Hofstede, G., (1980b), "Motivation, leadership and organization: Do American theories apply abroad?", Organizational Dynamics, vol. 9, no. 1, pp. 42-63.

Hofstede, G., (2001), Culture's consequences: comparing values, behaviors, institutions and organizations across nations, Sage, California.

Hofstede, G., \& Hofstede, G. J., (2005), Cultures and organizations: Software of the mind, McGraw-Hill, New York.

Hudson, M., Smart, A., \& Bourne, M., (2001), "Theory and practice in SME performance measurement systems", International Journal of Operations and Production Management, vol. 21, no. 8, pp. 1096-1115.

Huy, Q., (2001), "In praise of middle managers", Harvard Business Review, vol. 79, no. 8, pp. $72-79$.

Jarzabkowski, P., (2005), Strategy-as-practice: An activity-based approach, Sage, London.

Jarzabkowski, P., (2008), "Shaping strategy as a structuration process", Academy of Management Journal, vol. 51, no. 4, pp. 621-650.

Jarzabkowski, P., \& Spee, A., (2009), "Strategy as practice: A review and future directions for the field", International Journal of Management Reviews, vol. 11, no. 1, pp. 69-75.

Jarzabkowski, P., Balogun, J., \& Seidl, D., (2007), "Strategizing: The challenges of a practice perspective", Human Relations, vol. 60, no. 1, pp. 5-27.

Javidan, M., De Luque, M., House, R., Dorfman, P., Hanges, P., \& Javidan, M., (2006), "Conceptualizing and measuring cultures and their consequences: A comparative review of GLOBE's and Hofstede's approaches", Journal of International Business Studies, vol. 37, no. 6, pp. 897-914.

Johnson, G., Melin, L., Whittington, R., (2003), "Micro strategy and strategizing: Towards an activity-based view", Journal of Management Studies, vol. 40, no. 1, pp. 3-22.

Kellermanns, F., Walter, J., Lechner, C., \& Floyd, S., (2005), "The lack of consensus about strategic consensus: Advancing theory and research", Journal of Management, vol. 31, no. 5, pp. 719-737.

Khatri, N., (2009), "Consequences of power distance orientation in organisations", Vision, vol. 13 , no. 1, pp. 1-9.

Kirkman, B. L., Chen, G., Farh, J. L., Chen, Z. X., \& Lowe, K. B., (2009), "Individual power distance orientation and follower reactions to transformational leaders: A cross-level, cross-cultural examination", Academy of Management Journal, vol. 52, no. 4, pp. 744764.

Koc, E., (2013), "Power distance and its implications for upward communication and empowerment: Crisis management and recovery in hospitality services", International Journal of Human Resource Management, vol. 24, no. 19, pp. 3681-3696.

Kopelman, S., (2009), "The effect of culture and power on cooperation in commons dilemmas: Implications for global resource management", Organizational Behavior and Human Decision Processes, vol. 108, no. 1, pp. 153-163.

Krause, R., Filatotchev, I., \& Bruton, G., (2016), "When in Rome, look like Caesar? Investigating the link between demand-side cultural power distance and CEO power", Academy of Management Journal, vol. 59, no. 4, pp. 1361-1384. 
Laforet, S., (2016), "Effects of organisational culture on organisational innovation performance in family firms", Journal of Small Business and Enterprise Development, vol. 23, no. 2, pp. 379-407.

Langley, A., \& Royer, I., (2006), "Perspectives on doing case study research in organizations", Management, vol. 9, no. 3, pp. 81-94.

Miller, S., Hickson, D., \& Wilson, D., (2008), "From strategy to action: Involvement and influence in top level decisions", Long Range Planning, vol. 41, no. 6, pp. 606-628.

Noy, C., (2008), "Sampling knowledge: the hermeneutics of snowball sampling in qualitative research", International Journal of Social Research Methodology, vol. 11, no. 4, pp. 327-344.

Paulus, T., Bichelmeyer, B., Malopinsky, L., Pereira, M., \& Rastogi, P., (2005), "Power distance and group dynamics of an international project team: A case study", Teaching in Higher Education, vol. 10, no. 1, pp. 43-55.

Powell, T., Lovallo, D., \& Fox, C., (2011), "Behavioral strategy", Strategic Management Journal, vol. 32, no. 13, pp. 1369-1386.

Raes, A., Heijltjes, M., Glunk, U., \& Roe, R., (2011), "The interface of the top management team and middle managers: A process model", Academy of Management Review, vol. 36, no. 1, pp. 102-126.

Rigby, D., Reichheld, F., Schefter, P., (2002), "Avoid the four perils of CRM", Harvard Business Review, vol. 80, no. 2, pp. 101-109.

Roulston, K., (2010), "Considering quality in qualitative interviewing", Qualitative Research, vol. 10, no. 2, pp. 199-228.

Saunders, M., Lewis, P., \& Thornhill, A., (2016), "Research methods for business students (7th Ed.), Pearson Education Limited, England.

Schuder, K., (2016), "Using followership to develop new leadership in cultures with greater power distance", Journal of Leadership Studies, vol. 10, no. 3, pp. 58-61.

Shahzad, U., Memon, M. A., Khurram, S., \& Tan, K. L., (2019), "The role of relationship conflict and mindfulness in the consequences of task conflict", Asian Journal of Business Research, vol. 9, no. 3, pp.145-159.

Sriramesh, K., (2013), "Power distance and public relations: An ethnographic study of Southern Indian organizations", International Public Relations, pp. 181-200.

Stake, R. E., (2000), Handbook of qualitative research, Sage, Thousand Oaks.

Struwig, F., \& Smith, E., (2002), "The relationship between organisational culture and strategy formulation in South African firms", South African Journal of Business Management, vol. 33, no. 1, pp. 21-29.

Sull, D., Homkes, R., \& Sull, C., (2015), "Why strategy execution unravels - and what to do about it", Harvard Business Review, vol. 93, no. 3, pp. 57-66.

Thomas, D., (2006), "A General inductive approach for analysing qualitative evaluation data", American Journal of Evaluation, vol. 27, no. 2, pp. 237-246.

Ukil, M, Akkas, M., (2017), "Determining success factors for effective strategic change: Role of middle managers' strategic involvement", Serbian Journal of Management, vol. 12, no. 1, pp. 29-40.

Wang, Y., \& Larimo, J., (2017), "Ownership strategy and subsidiary survival in foreign acquisitions: The moderating effects of experience, cultural distance, and host country development", In Distance in international business: concept, cost and value, Emerald Publishing Limited, pp. 157-182.

Whittington, R., (2006), "Completing the practice turn in strategy research", Organization Studies, vol. 27, no. 5, pp. 613-634.

Willis, B., (2014), "The advantages and limitations of single case study analysis", EInternational Relations, vol. 4, pp. 1-7.

Wooldridge, B., \& Floyd, S., (1990), "The strategy process, middle management involvement, and organizational performance", Strategic Management Journal, vol. 11, no. 3, pp. 231-241. 
Wooldridge, B., Schmid, T., \& Floyd, S., (2008), "The middle manager perspective on strategy process: Contributions, synthesis, and future research", Journal of Management, vol. 34, no. 6, pp. 1190-1221.

Xiong Chen, Z., \& Aryee, S., (2007), "Delegation and employee work outcomes: An examination of the cultural context of mediating processes in China", Academy of Management Journal, vol. 50, no. 1, pp. 226-238.

Yan, M., (2008), "Exploring cultural tensions in cross-cultural social work practice", Social Work, vol. 53, no. 4, pp. 317-328.

Yan, M., (2008), "Exploring the meaning of crowing and culture: An empirical understanding from practitioners' everyday experience", Families in Society, vol. 89, no. 2, pp. 282292.

Yang, J., Mossholder, K., \& Peng, T., (2007), "Procedural justice climate and group power distance: An examination of cross-level interaction effects", Journal of Applied Psychology, vol. 92, no. 3, pp. 681-692.

Yin, R., (2014), Case study research: Design and methods (5th Ed.), Sage, Thousand Oaks.

Yuan, F., \& Zhou, J., (2015), "Effects of cultural power distance on group creativity and individual group member creativity", Journal of Organizational Behavior, vol. 36, no. 7, pp. 990-1007.

Zheng, W., Yang, B., \& McLean, G., (2010), "Linking organizational culture, structure, strategy, and organizational effectiveness: Mediating role of knowledge management", Journal of Business Research, vol. 63, no. 7, pp. 763-771. 